\title{
FATORES QUE AFETAM O VALOR NUTRITIVO DA SILAGENS DE FORRAGEIRASTROPICAIS
}

\author{
FACTORS AFFECTING THE NUTRITIVE VALUE TROPICAL FORAGES SILAGES
}

\author{
Santos, M.V.F. ${ }^{*}$, Gómez Castro, A.G. ${ }^{2}$, Perea, J.M. ${ }^{2}$, García, A. ${ }^{2}$, Guim, A. ${ }^{1}$ \\ e Pérez Hernández, M. $^{2}$
}

\begin{abstract}
1Universidade Federal Rural de Pernambuco. CEP 52171-900. Pernambuco. Brasil.mercia@dz.ufrpe.br ${ }^{2}$ Departamento de Producción Animal. Universidad de Córdoba. Campus de Rabanales. 14014 Córdoba. España.
\end{abstract}

\section{Palavras chave adicionais}

Aditivos. Composição química. Conservação de forragem. Parâmetros fermentativos.

\section{RESUMO}

Considerando a importância do uso da ensilagem como alternativa dos sistemas de alimentação animal, essa revisão objetiva apresentar resultados recentes disponíveis na literatura sobre alguns fatores que afetam o valor nutritivo da silagem, notadamente de forrageiras tropicais. A utilização de silagem na alimentação animal é uma prática importante na sustentabilidade dos sistemas produtivos, considerando os custos com alimentação animal, principalmente nos períodos seco do ano. A ensilagem de subprodutos da indústria pode ser uma importante ferramenta para diminuir a dependência de insumos externos, além de diminuir a contaminação ambiental por esses resíduos. As mudanças e perdas durante a ensilagem são influenciadas pelas características da planta forrageira e estão também associadas às práticas de manejo, colheita e armazenamento. Os fatores que influenciam no processo de ensilagem são muitos e agem isoladamente ou interagem entre si, que precisam ser considerados para obtenção de silagem de maior qualidade e mais estáveis. Resultados sobre a aplicação de aditivos enzimáticos ou sua associação com inoculantes em forrageiras tropicais são controversos na literatura disponível e dependentes das condições locais, concentração e tipo de inoculante, método de aplicação, qualidade da planta forrageira, microflora pré-existente, entre outros fatores.

\section{Additional KEYWORDS}

Additives. Chemical composition. Forage Conservation. Fermentative parameters.

\section{SUMMARY}

Considering the importance of silage as alternative for animal feeding systems, this review aims to present recent results available in literature on factors affecting the nutritive value of silage, especially in tropical forages. Considering the cost of feed, the use of silage as animal feed is an important practice in the sustainability of production systems, especially in dry periods of the year. The ensiling of by-products of industry may be an important tool to reduce the dependence on external inputs, and reduce the environmental contamination by these residues. Changes and losses during ensilage are influenced by the characteristics of the fodder plant and are also associated with management, harvesting and storage practices. The factors that influence the process of ensilage are numerous and act alone or interact with each other, which should be considered to obtain silage of higher quality and more stable. In relation with the application of, enzymatic additives or its association with inoculants, in tropical forage, the results available in the literature are controversial and dependent on local conditions, concentration and type of inoculum, method of application, quality of forage plant, and present microflora, among other factors.

\section{INTRODUÇÃO}

O uso de silagens de forrageiras tropicias 


\section{SANTOS, GÓMEZ CASTRO, PEREA, GARCÍA, GUIM E PÉREZ HERNÁNDEZ}

ou de restos de culturas tem se tornado cada vez maior na produção animal, notadamente de ruminantes, como forma de utilização do excedente da produção de forragem do período favorável do ano para minimizar a questão de escassez de alimento no período seco.

A utilização da ensilagem de restos de cultura ou subprodutos da indústria é uma forma de diminuir a contaminação ambiental por grande quantidade de resíduos vegetais, além de ser mais uma alternativa para o produtor rural como suporte alimentar, diminuindo a dependência de insumos externos.

A ensilagem é um método de conservação que compreende o armazenamento da forragem em condições de anaerobiose, objetivando o desenvolvimento de bactérias produtoras de ácido lático a partir de substratos como açúcares solúveis, ácidos orgânicos e compostos nitrogenados solúveis. Durante o processo ocorre diminuição do $\mathrm{pH}$ da massa ensilada e aumento de temperatura e nitrogênio amoniacal.

As plantas forrageiras normalmente são contaminadas por microrganismos epífitas e o desenvolvimento de cada tipo de organismo dependerá das condições encontradas no meio. $\mathrm{Na}$ ensilagem, a presença ou ausência de $\mathrm{O}_{2}$ no interior do silo determinará o desenvolvimento, mesmo que temporário, de três tipos de microrganismos: aeróbios, anaeróbios e anaeróbios facultativos. Bactérias ácido láticas são os principais microrganismos que atuam no processo fermentativo para a conservação da massa ensilada. Essas bactérias incluem, principalmente, os gêneros Lactobacillus, Streptococcus, Pediococcus e Leuconostoc, que produzem principalmente ácido lático como produto da fermentação dos açúcares. Já as bactérias anaeróbias do gênero Clostridium têm efeitos negativos sobre a qualidade da silagem (Jobim et al., 2001).

Tem sido crescente em diferentes locais, particularmente Europa e sul do Brasil, a ensilagem de forragem pré-secada em fardos revestidos com plástico especial. Conforme Pereira e Reis (2001), este processo tem como vantagens: i) Permitir o uso de equipamentos empregados no processo de fenação para produção de silagem; ii) Possibilitar o transporte de pequenas quantidades de forragem conservada sem abertura de silos e iii) Não requerer estruturas de silos. Por outro lado, como desvantagens apresentam: i) Investimento elevado na aquisição de equipamentos e do plástico apropriado, é uma alternativa mais viável para empresas que comercializam volumosos e ii) O tempo de conservação da forragem é menor que dos silos convencionais.

As forragens conservadas podem ter seu valor alimentício alterado, devido os procedimentos utilizados para a sua produção e conservação, e dos fenômenos bioquímicos e microbiológicos que ocorrem no processo (Jobim et al., 2007). Por outro lado, a resposta do animal à silagem é dependente do padrão de fermentação, que por sua vez exerce influência marcante na composição química, ingestão e digestibilidade da forragem. Krizsan e Randby (2007), ao avaliarem o valor nutritivo de 24 silagens de gramínes, observaram que as concentrações de ácido propiônico, butirico e lático foram as características que mais se correlacionaram ao consumo voluntário dos animais.

As gramíneas forrageiras tropicais, segundo Bergamaschine et al. (2006), não apresentam teores adequados de MS, de carboidratos solúveis e valores de poder tampão que proporcionem eficiente processo fermentativo. Estas situações podem ser modificadas pelo uso de técnicas como a mistura de produtos à massa ensilada (aditivos). Bernardes et al. (2005) observaram que a deterioração aeróbia em silagens de capins tropicais é caracterizada principalmente por bactérias aeróbias, em vez de fungos e leveduras, por estas apresentarem alto teor de umidade, reduzida acidez e baixa 
fonte de nutrientes disponíveis na massa ensilada.

$\mathrm{O}$ uso de aditivos que aumentem a eficiência do processo de ensilagem tem sido objeto de diferentes estudos. A redução dos conteúdos de fibra em detergente neutro e de fibra em detergente ácido da forragem ensilada pela adição de enzimas fibrolíticas é uma das vantagens a ser destacada, tendo em vista a possibilidade de aumento da ingestão e da eficiência da digestão de matéria seca, quando oferecida aos ruminantes (Cysneiros et al., 2006).

Vale ressaltar que a literatura disponível evidencia efeitos contraditórios de uso de aditivos e de outras técnicas utilizadas na ensilagem. Assim, o presente trabalho objetiva apresentar alguns resultados recentes disponíveis na literatura sobre alguns fatores que afetam o valor nutritivo da silagem, notadamente de forrageiras tropicais.

\section{FATORES QUE AFETAM A QUA- LIDADE DA SILAGEM}

As mudanças e/ou perdas durante a ensilagem são influenciadas pelas características da planta forrageira e estão também associadas às práticas de manejo, colheita e armazenamento. Diferenças entre genótipos (Mittelmann et al., 2005; Ruiz et al., 2009), composição química e estádio de maturação da planta (Vilela et al., 2008), tempo de exposição ao ar antes da ensilagem (Velho et al., 2006a), tempo de exposição ao ar após a desensilagem (Schocken-Iturrino et al., 2005), prática do emurchecimento

Tabela I. Média, desvio padrão e amplitude de concentração de nutrientes encontrados em 136 silagens de gramíneas. (Medium, standart error and amplitud of nutrient concentration in 136 grass silages).

\begin{tabular}{|c|c|c|c|c|}
\hline Item & Média & Desvio padrão & Mínimo & Máximo \\
\hline MS, \% peso fresco & 21,9 & 4,34 & 15,5 & 41,3 \\
\hline $\mathrm{PB}^{1}$ & 13,3 & 2,44 & 7,9 & 21,2 \\
\hline Energia bruta, MJ/Kg de MS & 18,5 & 0,62 & 16,7 & 20,4 \\
\hline Cinzas $^{1}$ & 7,9 & 1,30 & 4,9 & 12,4 \\
\hline $\mathrm{FDA}^{1}$ & 35,3 & 3,58 & 26,8 & 45,1 \\
\hline $\mathrm{FDN}^{1}$ & 54,4 & 5,10 & 41,3 & 66,2 \\
\hline Lignina $^{1}$ & 4,8 & 1,42 & 2,5 & 10,0 \\
\hline $\mathrm{EE}^{1}$ & 3,6 & 0,80 & 2,1 & 5,8 \\
\hline Carboidratos solúveis $^{1}$ & 1,1 & 1,57 & 0,2 & 10,7 \\
\hline PB solúvel ${ }^{1}$ & 7,6 & 1,69 & 3,9 & 12,9 \\
\hline Proteína verdadeira ${ }^{1}$ & 6,3 & 1,13 & 4,0 & 11,0 \\
\hline $\mathrm{Ph}$ & 4,2 & 0,40 & 3,5 & 5,5 \\
\hline Nitrogênio amôniacal/ $\mathrm{N}$ total $\left.\right|^{2}$ & 12,4 & 6,37 & 4,5 & 38,5 \\
\hline Ácido acético ${ }^{2}$ & 2,9 & 1,27 & 0,5 & 6,3 \\
\hline Ácido propiônico² & 0,4 & 0,31 & 0 & 1,3 \\
\hline Ácido butírico ${ }^{2}$ & 0,7 & 0,71 & 0 & 3,2 \\
\hline Ácido valérico ${ }^{2}$ & 0 & 0,08 & 0 & 0,6 \\
\hline Ácido láctico² & 6,6 & 3,47 & 0 & 14,4 \\
\hline Etanol $^{2}$ & 0,8 & 0,46 & 0,2 & 3,3 \\
\hline Propanol $^{2}$ & 0,4 & 0,40 & 0 & 2,2 \\
\hline
\end{tabular}

${ }^{1}$ Concentração de nutrientes, base na \%MS, ao menos que determinado de outra forma. ${ }^{2}$ Variaveis de fermentação, base na \% MS. Fonte: Yan e Agnew (2004). 


\section{SANTOS, GÓMEZ CASTRO, PEREA, GARCÍA, GUIM E PÉREZ HERNÁNDEZ}

(Castro et al., 2006), densidade de compactação (Velho et al., 2007), uso de inoculantes enzimo-bacterianos (Rocha et $a l .$, 2006), entre outros, são fatores que afetam o processo fermentativo e, consequentemente, a qualidade do material ensilado.

Os vários fatores que influenciam a qualidade da forragem podem atuar de forma conjunta e/ou isolada e resultam em diferentes efeitos no processo fermentativo, conforme à especie forrageira utilizada e condições ambientais. Yan e Agnew (2004), trabalhando com silagens de 136 gramíneas de clima temperado, observaram grandes variações na composição química dessas, conforme seus valores de $\mathrm{pH}$, nitrogênio amoniacal e percentagem de matéria seca (tabela I).

\section{TAMANHO DA PARTÍCULAE COMPACTAÇÃO}

A redução no tamanho da partícula pode promover redução na fermentação butírica, proporcionar maior compactação e queda mais rápida do $\mathrm{pH}$ do material ensilado, além de menores perdas na desensilagem. Entretanto, vale salientar que em silagens sem emurchecimento, a redução do tamanho da partícula pode promover maiores perdas por efluentes, devido ao rompimento da parede celular e consequente perda do conteúdo celular.

Segundo McDonald et al. (1991), o tamanho de partícula inferior a 20-30 mm pode favorecer a disponibilidade de carboidratos solúveis e, consequentemente, estimular o crescimento das bactérias láticas. Neumann et al. (2007a), avaliando o efeito do tamanho de partículas (pequena: entre 0,2 e 0,6 cm, ou grande: entre 1,0 e 2,0 $\mathrm{cm})$ em silagens de milho, observaram que não houve efeito do tamanho de partícula sobre os valores médios de MS, PB, FDN, $\mathrm{pH}$ e N-NH$/ \mathrm{NT}_{3}$ da silagem. Por outro lado, as eficiências de compactação da matéria verde - MV (541, 1 contra 495,6 kg. $\left.\mathrm{m}^{-3}\right)$ e da matéria seca - MS $\left(164,1\right.$ contra $\left.139,3 \mathrm{~kg} \cdot \mathrm{m}^{-3}\right)$ foram maiores $(p<0,05)$ em silagens de partículas pequenas, em relação às silagens de partículas grandes, respectivamente. $\mathrm{O}$ menor tamanho da partícula facilitou o processo de ensilagem, uma vez que permitiu maior densidade de transporte do material colhido até o local de armazenamento, como também aumentou a eficiência do processo de compactação e permitiu melhor fermentação anaeróbica.

A redução no tamanho da partícula de silagem de capim Tanzânia (Panicum maximum Jacq) não influenciou as perdas totais (Loures et al., 2005), embora o tamanho menor tenha contribuído para garantir maior estabilidade aeróbica da silagem. Neumann et al. (2007b) avaliaram o efeito do tamanho de partícula $(0,2$ a $0,6 \mathrm{~cm}$ e 1,0 a $2,0 \mathrm{~cm})$ e da altura de corte das plantas de milho para ensilagem $(15,2 \mathrm{~cm}$ e $38,6 \mathrm{~cm})$ e observaram que não houve efeito da interação altura de colheita das plantas $\times$ tamanho de partícula sobre as perdas de MS, PB e FDN. Influências significativas das interações altura de colheita das plantas $\times$ estrato no silo e tamanho de partícula $\times$ estrato no silo foram observadas, respectivamente, sobre as perdas de MS e PB. Na análise das perdas de $\mathrm{PB}$, os maiores valores foram observados em silagens de partículas pequenas no estrato superior $(18,96 \%)$ e em silagens de partículas grandes no estrato inferior $(18,68 \%)$, comparativamente às silagens com partículas pequenas no estrato inferior $(11,52 \%)$ e às silagens de partículas grandes no estrato superior (17,54\%). A silagem com partícula grande resultou em maiores perdas físicas no descarregamento da silagem.

No processo de ensilagem, para obtenção de fermentação desejada é fundamental a condição de anaerobiose no interior do silo, dependente principalmente da efetiva compactação. A facilidade de compactação do material é dependente do teor de matéria seca na forragem, bem como do tamanho da partícula, no momento da ensilagem. 
Amaral et al.(2007), estudando silagens de capim-marandu (Brachiaria brizantha Stapf (Hoch ex A. Rich)) produzidas com quatro pressões de compactação $(100,120$, 140 e $160 \mathrm{~kg} \mathrm{MS} . \mathrm{m}^{-3}$ ) durante a ensilagem, observaram que as silagens produzidas com menores pressões de compactação, apresentaram maior intensidade de produção de gases. Nas maiores pressões de compactação, houve maior preservação dos teores de MS das silagens. Os valores de $\mathrm{pH}$ das silagens mais bem compactadas foram reduzidos, em comparação aos daquelas com menor compactação, indicando que a maior densidade promoveu melhor ambiente para as bactérias produtoras de ácido lático. A maior intensificação na compactação promoveu decréscimo nos valores de nitrogênio insolúvel em detergente neutro (NIDN), FDN e FDA e aumento na recuperação de MS e na digestibilidade verdadeira in vitro da MS (tabela II).

\section{EMURCHECIMENTOETEMPODE EXPOSIÇÃO AO AR}

$\mathrm{O}$ emurchecimento promove maior concentração de substrato fermentáveis, dificultando o desenvolvimento de bácterias indesejáveis devido à diminuição da atividade da água ou elevação da pressão osmótica, além de contribuir para diminuição de efluentes. Por outro lado, elevados tempos de emurchecimento podem acarretar em consumo de carbohidratos solúveis da forragem, diminuindo a qualidade do material, bem como aumentar o número de fungos e leveduras no material a ser ensilado.

As silagens com maior conteúdo de MS estabilizam em pH mais alto devido a menor atividade de bactérias do gênero Clostridium que são sensíveis à pressão osmótica (Woolford, 1984). Conforme Pereira e Reis (2001), o ideal para o processo de ensilagem é que a forragem apresente teores de MS entre 35 e $45 \%$, sendo que nos teores entre 40 a $45 \%$ é recomendável que a forragem seja picada em partículas menores, a fim de se conseguir melhor compactação.

Trabalhando com silagens de capimtifton 85 (Cynodon $\mathrm{sp}$ ) confeccionadas com cinco teores de matéria seca, Castro et al. (2006) observaram que o emurchecimento a teores médios de MS de $450 \mathrm{~g} / \mathrm{kg} \mathrm{MS}$ favoreceu os parâmetros de fermentação (pH, N-NH $\mathrm{N}_{3}$ e poder tampão). Os maiores valores de $\mathrm{N}-\mathrm{NH}_{3}$ nas silagens com menor conteúdo de MS (250 g/kg MS), demons-

Tabela II. Características de silagens de capim-marandu no momento da abertura dos silos, conforme a pressão de compactação. (Characteristics of silages of marandu grass at the opening of the silos, as the packing densities).

\begin{tabular}{|c|c|c|c|c|c|c|c|c|}
\hline \multirow[b]{2}{*}{ Item } & \multicolumn{4}{|c|}{ Pressão de compatação } & \multirow[b]{2}{*}{ Média } & \multirow[b]{2}{*}{$\mathrm{Pr}>\mathrm{F}^{1}$} & \multirow[b]{2}{*}{ CV } & \multirow[b]{2}{*}{$\begin{array}{l}\text { EPda } \\
\text { média }\end{array}$} \\
\hline & $\begin{array}{l}100 \mathrm{~kg} \\
\mathrm{MS} \cdot \mathrm{m}^{-3}\end{array}$ & $\begin{array}{l}120 \mathrm{~kg} \\
\mathrm{MS}^{-\mathrm{m}^{-3}}\end{array}$ & $\begin{array}{l}140 \mathrm{~kg} \\
\mathrm{MS} . \mathrm{m}^{-3}\end{array}$ & $\begin{array}{l}160 \mathrm{~kg} \\
\mathrm{MS} \cdot \mathrm{m}^{-3}\end{array}$ & & & & \\
\hline Perdas de gás, \% MS & $7,8^{\mathrm{ab}}$ & $12,8^{\mathrm{a}}$ & $5,2^{\mathrm{b}}$ & $6,0^{\mathrm{b}}$ & 8,0 & ** & 34,1 & 1,4 \\
\hline Efluente, kg/t MV & $2,2^{\mathrm{a}}$ & $4,9^{\mathrm{a}}$ & $7,6^{\mathrm{a}}$ & $9,8^{\mathrm{a}}$ & 6,1 & 0,4 & 105,4 & 3,2 \\
\hline $\mathrm{MS}, \%$ & $27,8^{b}$ & $28,4^{b}$ & $32,7^{a}$ & $31,2^{\mathrm{ab}}$ & 30,0 & $* \star$ & 5,4 & 0,8 \\
\hline $\mathrm{pH}$ & $6,8^{\mathrm{a}}$ & $6,8^{\mathrm{a}}$ & $4,9^{b}$ & $4,8^{b}$ & 5,8 & * & 16,1 & 0,5 \\
\hline $\mathrm{N}-\mathrm{NH}_{3}, \% \mathrm{~N}$-total & $9,5^{\mathrm{a}}$ & $10,4^{\mathrm{a}}$ & $11,5^{\mathrm{a}}$ & $9,6^{a}$ & 10,2 & 0,8 & 33,7 & 1,7 \\
\hline Recuperação de MS, \% & $83,1^{\mathrm{b}}$ & $83,5^{\mathrm{b}}$ & $94,4^{\mathrm{a}}$ & $96,4^{\mathrm{a}}$ & 91,9 & ** & 4,9 & 2,3 \\
\hline DIVMS, \% & $55,7^{\mathrm{b}}$ & $52,8^{\mathrm{b}}$ & $58,6^{\mathrm{ab}}$ & $62,4^{\mathrm{a}}$ & 57,4 & * & 6,4 & 1,8 \\
\hline
\end{tabular}

Médias seguidas da mesma letra não diferem ( $p>0,05)$ : ${ }^{1} \mathrm{Pr}>\mathrm{F}$ : valor de $p .{ }^{*} \mathrm{p}<0,05 ;{ }^{* *} p<0,01$ Fonte: Amaral et al. (2007). 


\section{SANTOS, GÓMEZ CASTRO, PEREA, GARCÍA, GUIM E PÉREZ HERNÁNDEZ}

traram haver proteólise intensa nas forragens mais úmidas. O valor de NDT das silagens diminuiu significativamente com o aumento do conteúdo de MS a partir de 16 dias de estocagem, como reflexo da tendência de aumento nos conteúdos de FDN, FDA, LIG, NIDN e NIDA e redução no teor de EE.

Com o emurchecimento de forragens antes da ensilagem se pode reduzir por volatilização determinados fatores antinutricionais, como em plantas de Gliricidia sepium (Jacq.) Walp. que perdem metabólitos secundários a medida que o material é exposto ao sol. Por outro lado, Cabral Jr et al. (2007) observaram que à medida que a Gliricidia era exposta ao ar, ocorria perda de açúcares na ordem de $0,57 \%$. A maior quantidade encontrada de leveduras foi de 2,91 log ufc $\mathrm{g}^{-1} \mathrm{MS}$ (ponto de máximo) às 14,39 horas após o início do emurchecimento.

Fermentações indesejáveis e perdas excessivas de matéria seca após a abertura do silo serão mais intensas, quanto maior for à qualidade da silagem e umidade do material, bem como a temperatura ambiente, umidade do ar e tempo de exposição.

Velho et al. (2006b) observaram que os crescentes tempos de exposição ao ar após abertura dos silos (12, 24 e 36 horas) diminuiram o valor nutricional da silagem de milho por meio de significativos aumentos nas proporções de fibra em detergente neutro e de lignina, com diminuição dos carbohidratos não estruturais. Concluiu-se que a exposição ao ar por um período de 12 horas após a abertura dos silos afetou o valor nutritivo da silagem de milho.

Por outro lado, Mattos et al. (2005), trabalhando com silagem de Maniçoba (Manihot $\mathrm{sp}$ ), observaram que a exposição ao ar influenciou apenas a degradabilidade efetiva (DE) da MS, com menores valores da silagem exposta por seis dias, e a DE da FDN, sendo que a silagem que não foi exposta ao ar apresentou melhores valores, confirmando a utilização da FDN na produção de
$\mathrm{CO}_{2}$. A silagem de maniçoba apresentou baixa velocidade de deterioração aeróbica, com baixa produção de gás carbônico até doze dias de exposição ao ar.

O emprego da prática de emurchecimento dependerá das características da planta a ser ensilada e da sua duração, conforme as condições ambientais. O tempo da exposição da silagem ao ar deve ser mínimo, o qual pode ser alcançado com o manejo de fatias diárias com o máximo de $15 \mathrm{~cm}$, evitando fermentações indesejáveis e perdas excessivas de matéria seca após a abertura do silo.

\section{ADITIVOS}

Aditivos de silagens são aqueles produtos que podem ser adicionadas às forragens ensiladas para melhorar a fermentação ou reduzir perdas, podendo ser classificados em inibidores e estimuladores de fermentação (Woolford, 1984).

Conforme McDonald et al. (1991), os aditivos para ensilagem podem ser classificados em quatro tipos: i) Estimulantes - são acúcares ou produtos ricos em carboidratos, estimulam o crescimento de bacterias lácticas; ii) Inhibidores - diminuem o crescimento de microorganismos, como exemplo o ácido fórmico e o formaldeído; iii) Inibidores de deteriorizaçao aeróbica controlam a deteriorização causada pelo ar quando o silo é aberto, exemplo ácido propiónico e uréia e iv) Nutrientes - se adicionam na forragem a ser ensilada para melhorar o valor nutritivo da silagem.

\section{Aditivos ABSORVENTES}

A adição de um produto com alto teor de MS funciona como aditivo absorvente, elevando o teor de MS do material ensilado, o que torna o ambiente menos favorável para o desenvolvimento das leveduras e contribui para menores perdas de efluentes. Aditivos para elevar os teores de carboidratos solúveis também são utilizados como forma de melhorar o substrato para fermentação. 
Entretanto, conforme observado por Vieira et al. (2007), alguns aditivos melhoram a composição química da silagem, porém podem comprometer o processo fermentativo.

$\mathrm{O}$ uso de silagens de cana-de açúcar poderá ser potencializado com o emprego de aditivos que visem o controle de crescimento de leveduras, uma vez que ocorrem mudanças na composição química dessas silagens sem o uso de aditivos. Pedroso et al. (2005) observaram que em silagem de cana, o etanol atingiu $6,4 \%$ na MS no 150 dia após ensilagem, seguido pelo desaparecimento de $71 \%$ dos carboidratos solúveis - CHOs. As perdas gasosas e a perda total de MS estabilizaram-se após 45 dias (16\% e $29 \%$ da MS). A contagem de leveduras foi máxima no segundo dia $(5,05$ $\left.\log \mathrm{ufc}^{-1}\right)$. O pH atingiu nível abaixo de 4,0 no terceiro dia. A produção de efluentes foi insignificante $\left(20,1 \mathrm{~kg}^{\mathrm{t}-1}\right)$. O teor de MS da forragem decresceu (35\% para $26 \%$ ) do dia 0 ao $45^{\circ}$ dia. O padrão de variação na concentração de etanol foi inverso à concentração de CHOs.

Silagem de cana-de-açúcar acrescida de uréia e aditivos absorventes de umidade foi estudada por Lopes et al. (2007) que testaram diferentes quantidades de aditivos (com base na matéria verde da forragem): $1,5 \%$ uréia; $0,5 \%$ uréia $+4 \%$ fubá; $0,5 \%$ uréia $+4 \%$ de mandioca desidratada; $1,5 \%$ de uréia; e cana-de-açúcar pura. $\mathrm{O}$ valor nutritivo da silagem de cana-de-açúcar foi aumentado com o uso de aditivos, implicando maior consumo e digestibilidade da PB (tabela III).

Bernardino et al. (2005) avaliaram os efeitos da adição de 10, 20,30 e 40\% de casca de café ao capim-elefante (Pennisetum purpureum Schum), com base na matéria natural, sobre a composição bromatológica e a produção e composição do efluente resultante do processo de ensilagem. A casca de café foi eficiente na redução da umidade da silagem, estimando-se acréscimo de $0,69 \%$ no teor de matéria seca para cada unidade percentual de casca adicionada. Houve redução linear do $\mathrm{pH}$ com o aumento dos níveis do aditivo. Verificou-se efeito quadrático da adição de casca de café nos teores de proteína bruta, estimando-se teor máximo de $10,0 \%$ com a adição de $26,3 \%$ de casca. A adição de casca promoveu reduções nos teores de nitrogênio amoniacal, fibra em detergente neutro e na DIVMS e aumentos lineares dos teores de nitrogênio insolúvel em detergente ácido e lignina. Os teores de fibra em detergente ácido e de celulose não foram influenciados pela adição de casca de café (tabela IV). Observou-se produção de efluente apenas nas silagens com 0 e $10 \%$ de casca de café. Os autores concluíram que a

Tabela III. Coeficientes de digestibilidade dos nutrientes de silagens de cana-de-açúcar tratadas com aditivos. (Digestibility coefficients of nutrients of silage from sugar cane treated with additives).

\begin{tabular}{|c|c|c|c|c|}
\hline \multirow[b]{2}{*}{ Aditivo } & \multicolumn{4}{|c|}{ Coeficiente de digestibilidade (\%) } \\
\hline & MS & FDN & CNF & PB \\
\hline $1,5 \%$ de ureia & 45,92 & 43,96 & $57,81 b$ & $53,66^{a}$ \\
\hline $0,5 \%$ uréia $+4 \%$ de fubá & 48,22 & 35,61 & $81,50^{\mathrm{a}}$ & $53,99^{a}$ \\
\hline $0,5 \%$ de uréia $+4 \%$ de mandioca desidratada & 44,32 & 38,83 & $76,32^{\mathrm{ab}}$ & $55,64^{\mathrm{a}}$ \\
\hline $1,5 \%$ de amiréia & 47,91 & 38,24 & $76,33^{\mathrm{ab}}$ & $61,60^{\mathrm{a}}$ \\
\hline Silagem de cana-de-açúcar pura & 44,22 & 37,13 & $85,38^{a}$ & 27,75 \\
\hline Média & 46,12 & 38,40 & 75,47 & 50,53 \\
\hline CV (\%) & 13,28 & 20,88 & 12,13 & 18.18 \\
\hline
\end{tabular}

Fonte: Lopes et al. (2007). 


\section{SANTOS, GÓMEZ CASTRO, PEREA, GARCÍA, GUIM E PÉREZ HERNÁNDEZ}

adição de $20 \%$ de casca de café garantiu boa preservação da silagem e eliminou a produção de efluente.

A polpa cítrica desidratada tem sido utilizada como aditivo em razão de seu alto teor de matéria seca e de carboidratos solúveis e de sua capacidade de absorver água. Com o objetivo de avaliar os benefícios desse aditivo sobre a qualidade de silagens de capim-elefante, Rodrigues et al. (2005a) testaram níveis crescentes de adição de polpa cítrica peletizada: $0 ; 2,5 ; 5 ; 7,5 ; 10$; 12,5 e $15 \%$, com base na matéria fresca ao capim-elefante no momento da ensilagem. Observou-se efeito linear crescente da adição de polpa cítrica sobre os teores de matéria seca, o mesmo ocorrendo nos carboidratos solúveis e digestibilidade in vitro da matéria seca, entretanto com redução nos teores de nitrogênio amoniacal e fibra em detergente neutro. Nos teores de ácidos orgânicos (acético, lático e butírico) e etanol, observou-se comportamento quadrático, com pontos de máximo no ácido lático igual a 5,8\% e de mínima nos ácidos acético, butírico e o etanol, iguais a 7,8; 7,2; e -3,7\% de polpa, respectivamente. Não se observou efeitos sobre os valores de $\mathrm{pH}$, assim como nos teores de lignina e de ácido propiônico. Os autores concluíram que inclusões de 4,7 a 7,6\% de polpa cítrica peletizada, com base na matéria fresca, foram suficientes para melhorar a qualidade da silagem de capimelefante. Ferrari Júnior et al. (2009), trabalhando com o capim Pennisetum hybridum $\mathrm{cv}$. Paraíso aos 100 dias de idade, observaram que as porcentagens de MS, PB, DIVMS e de ácido lático da silagem aumentaram com a adição de polpa cítrica até $10 \%$.

Em silagem de capim-elefante, Cândido et al. (2007) observaram que os níveis crescentes de SDM (subproduto desidratado de maracujá) proporcionaram efeito linear crescente sobre o teor de MS das silagens e efeito linear decrescente sobre o teor de ácido propiônico. Os teores de FDN e hemicelulose das silagens foram afetados pelos níveis crescentes de SDM, com resposta linear decrescente. A adição de SDM na ensilagem do capim-elefante favoreceu o processo fermentativo e melhorou a composição químico-bromatológica das silagens, portanto, esse subproduto pode ser utilizado em quantidades de até $14 \%$, em relação à matéria natural da gramínea.

Tabela IV. Composição bromatológica das silagens de capim-elefante, conforme o nível de adição de casca de café. (Chemical composition of elephant grass silages, as the level of addition of coffee hulls).

\begin{tabular}{|c|c|c|c|c|c|c|c|}
\hline \multirow[b]{2}{*}{ Ítem } & \multicolumn{5}{|c|}{ Nível de casca de café (\%) } & \multirow[t]{2}{*}{ Equação de regressão } & \multirow[t]{2}{*}{$r^{2}$} \\
\hline & 0 & 10 & 20 & 30 & 40 & & \\
\hline $\mathrm{MS}^{1}(\%)$ & 12,6 & 18,0 & 24,9 & 33,0 & 39,9 & $Y=11,7848+0,6948^{\star *} C$ & 0,99 \\
\hline $\mathrm{pH}^{1}$ & 5,1 & 4,7 & 4,4 & 4,1 & 4,0 & $Y=4,9835-0,0261^{* *} C$ & 0,96 \\
\hline $\mathrm{PB}^{1}(\% \mathrm{MS})$ & 5,8 & 9,2 & 9,5 & 9,6 & 9,2 & $Y=6,0840+0,3004^{\star *} C-0,0057^{\star *} C^{2}$ & 0,85 \\
\hline $\mathrm{N}-\mathrm{NH}_{3}{ }^{1}(\% \mathrm{NT})$ & 28,7 & 12,4 & 5,6 & 2,8 & 1,9 & $Y=24,8943^{\star *} 0,9337 \mathrm{C}$ & 0,95 \\
\hline $\operatorname{NIDA}^{1}(\% \mathrm{NT})$ & 16,4 & 21,8 & 24,5 & 26,6 & 27,9 & $\mathrm{Y}=17,8787+0,2778^{\star *} \mathrm{C}$ & 0,93 \\
\hline $\mathrm{FDN}^{1}(\% \mathrm{MS})$ & 74,3 & 73,1 & 67,6 & 66,5 & 66,6 & $Y=74,0394+0,2201^{* *} C$ & 0,85 \\
\hline $\mathrm{FDA}^{1}(\% \mathrm{MS})$ & 51,6 & 55,7 & 53,4 & 53,6 & 53,6 & & \\
\hline Lignina $^{1}(\% \mathrm{MS})$ & 8,4 & 11,1 & 12,7 & 14,1 & 14,0 & $Y=9,2599+0,1413^{* *} C$ & 0,89 \\
\hline Celulose $^{1}(\% \mathrm{MS})$ & 39,6 & 39,1 & 38,8 & 36,5 & 38,3 & & \\
\hline DIVMS (\%) & 57,6 & 50,1 & 47,4 & 49,6 & 45,7 & $Y=54,9219-9,2421^{\star *} C$ & 0,71 \\
\hline
\end{tabular}

'Valores observados; ${ }^{\star *} \mathrm{p}<0,01$ pelo teste "t". Fonte: Bernardino et al. (2005). 


\section{VALORNUTRITIVO DE SILAGENS DE FORRAGEIRAS TROPICAIS}

O resíduo da colheita da soja na ensilagem da cana-de-açúcar foi capaz de melhorar a qualidade nutritiva e reduzir as perdas de MS e a produção de etanol das silagens, afirmaram Freitas et al. (2006a), quando testaram diferentes níveis de inoculante microbiano e hidróxido de sódio, acrescida de $10 \%$ de resíduo da colheita de soja, com base no peso verde da cana. Freitas et al. (2006b) observaram que a associação do resíduo da colheita de soja à cana-de-açúcar proporcionou melhor qualidade nutritiva, com menores perdas de MS e carboidratos solúveis, principalmente na forma de gases, e, consequentemente, menor acúmulo dos componentes da parede celular, além de redução na DIVMS da forragem.

O tipo de aditivo absorvente a ser utilizado na ensilagem dependerá das caracteristicas do material a ser ensilado, da disponibilidade e custo do aditivo, conforme a região. Porém, fica evidente que quando o aditivo absorvente é utilizado em quantidades adequadas é capaz de proporcionar a elevação do teor de MS do material ensilado e promover ambiente menos favorável para o desenvolvimento das leveduras, contribuindo também para menores perdas por efluentes.

\section{AditivosenZIMo-Microbianos}

A utilização de enzimas fibrolíticas na ensilagem visa aumentar a eficiência do processo fermentativo, favorecendo a atuação de microorganismos desejáveis, como aquelas produtoras de ácido lático. As principais enzimas fibrolíticas utilizadas, como as hemicelulases, celulases, pectinases e xilanases, atuam disponibilizando açúcares simples como fonte de nutrientes para as bactérias fermentadoras (Muck e Kung Jr., 1997).

Resultados sobre a aplicação de aditivos enzimáticos ou sua associação com inoculantes bacterianos são controversos na literatura disponível. Vale ressaltar a influência das condições locais, concen- tração e tipo de inoculante, método de aplicação e qualidade da planta forrageira, entre outros fatores, sobre o efeito do inoculante na silagem. O uso de inoculantes microbianos é uma estratégia viável, porém a eficiência destes é também dependente da microflora pré-existente no material a ser ensilado.

Pereira et al. (2007) avaliaram dois aditivos enzimo amilolítico-bacterianos (Sil All C4 -Alltech do Brasil e Bacto Silo C Tropical -Katec) em seis períodos de fermentação (1, $3,7,14,28$ e 56 dias) sobre o $\mathrm{pH}$, relação $\mathrm{NH}_{3} /$ Ntotal, composição química, DIVMS e populações microbianas de silagens de capim-elefante. Os teores de PB, FND e FDA, foram influenciados apenas pelo período de fermentação, enquanto na DIVMS observou-se efeito da interação aditivo $\times$ período de fermentação. Nos valores de pH se observou efeito tanto dos aditivos (silagens tratadas com Sill All apresentaram menor valor) como do período de fermentação, estimando-se reduções de 0,$5769 ; 0,62327$ e 0,80218 unidades/dia de fermentação nas silagens controle e tratadas com Sil All e Bacto Silo, respectivamente. No teor de $\mathrm{N}_{-} \mathrm{NH}_{3}$ se observou efeito da interação inoculante $\times$ período, porém a partir dos resultados encontrados nessa variável os autores afirmaram que todas as silagens foram bem preservadas. Nas populações microbianas quantificadas nas silagens de capim-elefante, os autores concluíram que são adequadas para a manutenção de uma boa fermentação no silo. Assim, considerando-se os baixos valores de $\mathrm{pH}$ e N-NH , a inclusão de aditivos enzimo-bacterianos mostrou-se desnecessária, uma vez que estes não alteram também a composição química e a digestibilidade das silagens.

Freitas et al. (2006a) testaram diferentes níveis de inoculante microbiano (Lactobacillus plantarum nas doses 1,0; 1,2 e 1,4 x 106 ufc. $\mathrm{g}^{-1} \mathrm{MN}$ ) e hidróxido de sódio (solução $40 \%$ na base de $3 \%$ da MS), acrescida de $10 \%$ de resíduo da colheita de 


\section{SANTOS, GÓMEZ CASTRO, PEREA, GARCÍA, GUIM E PÉREZ HERNÁNDEZ}

soja, com base no peso verde da cana-deaçúcar. O resíduo da colheita da soja na ensilagem da cana-de-açúcar foi capaz de melhorar a qualidade nutritiva e reduzir as perdas de MS e a produção de etanol das silagens. O tratamento com hidróxido de sódio diminuiu a produção de etanol, mas não melhorou a qualidade nutritiva e não reduziu as perdas de MS das silagens. A utilização de inoculante microbiano contendo L. plantarum também não melhorou a qualidade nutritiva da silagem, nem reduziu as perdas de MS e a produção de etanol.

As bactérias heterofermentativas, como o Lactobacillus buchneri é uma opção como aditvo, principalmente por promoverem maior estabilidade aérobica. Conforme Queiroz (2006), essas bactérias, além de produzirem ácido acético e lático, não produzem etanol, graças à ausência da enzima acetaldeído desidrogenase. Kleinschmit e Kung (2006), em trabalho de revisão, registraram que o uso da $L$. buchneri promoveu diminuição de $\mathrm{pH}$, da concentração de ácido lático e do número de leveduras, bem como elevou a concentração de ácido acético e promoveu maior estabilidade das silagens inoculadas. Os autores observaram que a inoculação aumentou a concentração de ácido propiônico e etanol e diminui a concentração de carboidratos solúveis nas silagens de gramíneas e com poucos grãos, porém não foi observado em silagem de milho (tabela V), o que sugere efeito específico microrganismo-cultura. Neste sentido, Ruiz et al. (2009) observaram que o efeito de enzimas fibrolíticas e inoculantes bacterianos usados em silagem de milho foi muito heterogêneo entre sete híbridos de milho avaliados, o que indica que a resposta obtida ao utilizar este tipo de produtos comerciais está influenciada por característica próprias da forragens utilizadas, sendo recomendável selecionar tanto o híbrido como o aditivo adequado para obter vantagens na relação custo-benefício.

Kleinschmit et al. (2005), trabalhando com silagem de milho, observaram que o $L$. buchneri 40788 aplicado na taxa de de $4 \times$ $105 \mathrm{ufc} / \mathrm{g}$ de massa, promoveu aumento da concentração de ácido acético e melhorou a estabilidade aeróbica (mais de 210 horas) em ambos os anos do estudo. Entretanto, as perdas de matéria seca não foram afetadas.

Tabela $\boldsymbol{V}$. Efeito de Lactobacillus buchneri nas caracteristicas de silagens de milho. (Effect of Lactobacillus buchneri on characteristics of silage of maize).

\begin{tabular}{lcccccccc}
\hline & & & & & & & \multicolumn{2}{c}{ Contraste, $\mathrm{P}^{2}$} \\
Item & ${ }^{1} \mathrm{LBO}$ & $\mathrm{N}$ & ${ }^{1} \mathrm{LB} 1$ & $\mathrm{n}$ & ${ }^{1} \mathrm{LB} 2$ & $\mathrm{n}$ & 1 & 2 \\
$\mathrm{MS}, \%$ & $30,7 \pm 1,1$ & 19 & $30,7 \pm 1,2$ & 7 & $30,7 \pm 1,1$ & 27 & 0,87 & 0,85 \\
$\mathrm{pH}$ & $3,70 \pm 0,03$ & 23 & $3,75 \pm 0,05$ & 9 & $3,88 \pm 0,03$ & 29 & $<0,01$ & 0,01 \\
Ác. lático, \% & $6,59 \pm 0,43$ & 24 & $5,87 \pm 0,50$ & 10 & $4,79 \pm 0,42$ & 29 & $<0,01<0,01$ \\
Ác. acetico, \% & $2,18 \pm 0,25$ & 24 & $2,63 \pm 0,27$ & 10 & $3,89 \pm 0,25$ & 29 & $<0,01<0,01$ \\
Ác. propionico, \% & $0,08 \pm 0,03$ & 11 & $0,06 \pm 0,05$ & 5 & $0,11 \pm 0,03$ & 12 & 0,96 & 0,27 \\
Etanol,\% $_{\mathrm{N}-\mathrm{NH}_{3}, \%}, \%$ & $1,62 \pm 0,23$ & 19 & $1,58 \pm 0,24$ & 9 & $1,47 \pm 0,23$ & 22 & 0,17 & 0,22 \\
Carboidratos solúveis,\% $^{2}$ & $0,018 \pm 0,013$ & 14 & $0,111 \pm 0,013$ & 9 & $0,115 \pm 0,013$ & 19 & 0,16 & 0,34 \\
Recuperacao de MS.\% $^{1,55 \pm 0,31}$ & 12 & $1,49 \pm 0,77$ & 5 & $1,32 \pm 0,30$ & 18 & 0,73 & 0,83 \\
Estabilidade aeróbica $^{3}$ & $95,5 \pm 0,9$ & 16 & $95,5 \pm 1,0$ & 8 & $94,5 \pm 0,9$ & 23 & 0,05 & 0,01 \\
& 25 & & 35 & & 503 & & & \\
\hline
\end{tabular}

${ }^{1}$ LBO- controle, LB1- Lactobacillus buchneri $\leq 1000.000 \mathrm{cfu} / \mathrm{g}$ de forragem fresca, LB2- Lactobacillus buchneri $>1000.000 \mathrm{cfu} / \mathrm{g}$ de forragem fresca; ${ }^{2} 1$ LBO vs. LB1 e 2 LB1 vs. LB2; ${ }^{3}$ Número de horas para aumento de 1 a $2^{\circ} \mathrm{C}$. Fonte: Kleinschmit e Kung (2006). 
Akintokun et al. (2007), estudando o efeito do L. plantarum e carbohidrase na microbiota da silagem de Tridax procumbens, observaram que o uso do inoculante ou da enzima promoveram diminuição no conteúdo bacteriano. Ao aumentar o tempo de conservação, houve redução de bactérias e especialmente de fungos, bem como de leveduras, notadamente aos 20 dias de ensilagem. Observou-se redução de $\mathrm{pH}$ e composição química coma a inclusão do inoculante e da enzima. Penteado et al. (2007), trabalhando com capim-mombaça (Panicum maximum Jacq), observaram que a inoculação com $L$. plantarum da microbiota epifítica melhorou o perfil fermentativo considerando com os valores de $\mathrm{pH}, \mathrm{NH}_{3}$, ácido lático e ácido acético e menores perdas de matéria seca na silagem.

Santos et al. (2008) observaram que a inclusão de inoculante (Sil All C4 da Altech do Brasil ) em leite desnatado reconstituído, diminuiu as perdas por gases, melhorou o perfil fermentativo, elevou a recuperação de MS e PB, e melhorou o valor nutricional da silagem de capim-tanzânia (Panicum maximum Jacq.) cortado aos 50 dias de rebrotação.

Por outro lado, Rodrigues et al. (2005b) não encontraram efeitos significativos da inoculação microbiana (S. faecium mais L. plantarum) em silagem de girassol (Helianthus annus L.) sobre a digestibilidade da matéria seca e demais nutrientes em carneiros, bem como o consumo de MS (2,49 vs 2,54\%PV). Grise et al. (2006) trabalharam com silagem de sorgo e observaram que o inoculante comercial SilAll (Alltech) não afetou significativamente os teores de $\mathrm{pH}, \mathrm{PB}, \mathrm{FDN}$ e FDA da silagem. Itavo et al. (2006) testaram o uso do inoculante microbiano comercial, composto por Lactobacillus plantarum e enzimas amilóliticas e nove tempos de armazenamento e observaram que o inoculante microbiano não promoveu alterações na composição química nem redução de perdas da MS nas silagens de grãos úmidos de milho e de sorgo.

As enzimas adicionadas na ensilagem deverão agir de maneira similar às bactérias que iniciam a digestão no rúmen, iniciando a digestão dos componentes estruturais da parede celular, o que cria sítios adicionais de digestão e a liberação de produtos que atraem as bactérias do rúmen aos sítios de digestão (Cysneiros et al., 2006). Assim, a incorporação de fungos ligninolíticos a forragem com alto conteúdo de fibra, como restos de culturas e a maioria das forrageiras tropicais, promove maior disponibilidade de compostos fermentáveis que favorece a conservação do material, além de favorecer a degradação e fermentação ruminal da fibra.

Jalilvand et al. (2008) observaram que misturas de enzimas fibrolíticas, particularmente Cellupract, melhoraram a digestibilidade da forragem. Peláez Acero et al. (2008) observaram que o uso de cana-deaçúcar integral pré-fermentadada aerobicamente por 48 horas e inoculada em seguida com Pleurotus sapidus resultou em aumento na produção total de gás, melhoria na digestibilidade e nos parâmetros fermentativos da silagem. Cysneiros et al. (2006) avaliaram o efeito de níveis de enzimas fibrolíticas $(0,5,10$ e $20 \mathrm{mg}$ de enzimas por $\mathrm{kg}$ de matéria natural) sobre a composição bromatológica da silagem de milho. Verificou-se que a solução enzimática não alterou o conteúdo de $\mathrm{MS}, \mathrm{pH}$ e N-NH$/ \mathrm{NT}$ da silagem. Na proteína bruta, não se observou diferença entre os períodos de armazenamento (45 e 120 dias), porém houve interação período de armazenamento e nível de enzima. Verificou-se aumento da PB no nível de 20 mg (10,14\%), em relação ao controle $(8,77 \%)$ no período de 45 dias. A solução enzimática alterou o teor da FDN na média do nível de enzimas. Observou-se redução da FDN do nível de $10 \mathrm{mg}(47,25 \%)$, em relação ao tratamento-testemunha $(49,96 \%)$.

Por outro lado, Coan et al. (2005) trabalharam com os capins Tanzânia e Mombaça e observaram que o inoculante 


\section{SANTOS, GÓMEZ CASTRO, PEREA, GARCÍA, GUIM E PÉREZ HERNÁNDEZ}

enzimático-bacteriano (hemicelulase, celulase e amilase e cepas tropicalizadas de Lactobacillus plantaruam, Enterococcus faecium e Pediococcus spp.) não proporcionou melhores características qualitativas, fermentativas e nutricionais das silagens avaliadas. Freitas et al.(2006b) não recomendaram a utilização dos inoculantes $L$. plantarum e L. buchneri na ensilagem da cana-de-açúcar, pois nenhuma melhoria foi observada na composição química ou no perfil de fermentação das silagens.

\section{Aditivosquímicos}

Diferentes aditivos, como uréia, benzoato de sódio e hidroxido de sódio, entre outros, tem sido utilizados como forma de melhorar as condições para

Tabela VI. Valores de pH, antes da ensilagem e após a abertura dos silos, perdas por gases e por efluentes em silagens de cana-de-açúcar tratadas com aditivos químicos e bacterianos. (PH values, before ensiling and after opening the silos, gas losses and effluent from sugar cane silage treated with chemical additives and bacterial).

\begin{tabular}{|c|c|c|c|c|}
\hline \multirow[b]{2}{*}{ Tratamento $^{1}$} & \multicolumn{4}{|c|}{ Ensilagem } \\
\hline & Controle & $\mathrm{PROP}^{2}$ & $\mathrm{BUCH}^{3}$ & Média \\
\hline \multicolumn{5}{|c|}{ Valores de $\mathrm{pH}$ antes da ensilagem } \\
\hline Controle & 5,9 & 5,6 & 5,7 & $5,8^{b}$ \\
\hline Uréia & 5,8 & 5,8 & 5,7 & $5,8^{b}$ \\
\hline Benzoato & 5,6 & 5,7 & 5,7 & $5,8^{\mathrm{b}}$ \\
\hline $\mathrm{NaOH}$ & 11,7 & 11,6 & 11,6 & $11,6^{\mathrm{a}}$ \\
\hline Média & $7,3^{\mathrm{A}}$ & $7,2^{\mathrm{B}}$ & $7,2^{\mathrm{B}}$ & 7,2 \\
\hline $\mathrm{CV} \%$ & & & & 7,1 \\
\hline \multicolumn{5}{|c|}{ Valores de $\mathrm{pH}$ na abertura dos silos } \\
\hline Controle & $3,7^{\mathrm{AbC}}$ & $3,5^{\mathrm{Bc}}$ & $3,4^{\mathrm{Bb}}$ & $3,6^{c}$ \\
\hline Uréia & $4,2^{\mathrm{Bb}}$ & $4,3^{\mathrm{Bb}}$ & $4,6^{\mathrm{Aa}}$ & $4,4^{b}$ \\
\hline Benzoato & $3,7^{\mathrm{Ac}}$ & $3,6^{A C}$ & $3,6^{\mathrm{Bb}}$ & $3,6^{c}$ \\
\hline $\mathrm{NaOH}$ & $4,6^{\mathrm{Aa}}$ & $4,6^{\mathrm{Aa}}$ & $4,5^{\mathrm{Ba}}$ & $4,6^{\mathrm{a}}$ \\
\hline Média & $4,1^{\mathrm{A}}$ & $4,0^{\mathrm{B}}$ & $4,0^{B}$ & 4,0 \\
\hline CV\% & & & & 1,40 \\
\hline \multicolumn{5}{|c|}{ Perdas por gases ( $\%$ da MS ensilada) } \\
\hline Controle & $15,9^{\mathrm{Ba}}$ & $19,9^{\text {Aa }}$ & $13,2^{\mathrm{Ca}}$ & $16,4^{\mathrm{a}}$ \\
\hline Uréia & $13,2^{\text {Aab }}$ & $13,9^{A b}$ & $12,2^{\text {Aa }}$ & $13,1^{\mathrm{b}}$ \\
\hline Benzoato & $11,2^{\mathrm{Abc}}$ & $12,6^{\mathrm{Ab}}$ & $7,3^{\mathrm{Bb}}$ & $10,4^{c}$ \\
\hline $\mathrm{NaOH}$ & $9,6^{A C}$ & $6,4^{\mathrm{BC}}$ & $6,2^{\mathrm{Bb}}$ & $7,4^{\mathrm{d}}$ \\
\hline Média & $12,5^{\mathrm{A}}$ & $13,2^{\mathrm{A}}$ & $9,7^{\mathrm{B}}$ & 11,8 \\
\hline $\mathrm{CV} \%$ & & & & 11,08 \\
\hline \multicolumn{5}{|c|}{ Perdas por efluentes (kg/t de MS ensilada) } \\
\hline Controle & $3,7^{\mathrm{AC}}$ & $3,5^{\mathrm{Bc}}$ & $3,4^{\mathrm{Bb}}$ & $3,6^{\mathrm{c}}$ \\
\hline Uréia & $4,2^{\mathrm{Bb}}$ & $4,3^{\mathrm{Bb}}$ & $4,6^{\mathrm{Aa}}$ & $4,4^{\mathrm{b}}$ \\
\hline Benzoato & $3,7^{\mathrm{Ac}}$ & $3,6^{A C}$ & $3,5^{\mathrm{Bb}}$ & $3,6^{c}$ \\
\hline $\mathrm{NaOH}$ & $4,6^{\mathrm{Aa}}$ & $4,6^{\mathrm{Aa}}$ & $4,5^{\mathrm{Ba}}$ & $4,6^{a}$ \\
\hline Média & $4,1^{\mathrm{A}}$ & $4,0^{\mathrm{B}}$ & $4,0^{B}$ & 4,0 \\
\hline CV\% & & & & 1,40 \\
\hline \multicolumn{5}{|c|}{$\begin{array}{l}\text { Médias seguidas de mesma letra, maiúscula na linha e minúscula na coluna, não diferem }(p<0,05) \text { pelo } \\
\text { teste de Tukey. }{ }^{1} 1,5 \% \text { de uréia; } 0,1 \% \text { de benzoato de sódio e } 1 \% \text { de hidróxido de sódio. }{ }^{2} \text { Propionibacterium } \\
\text { acidipropionici }+ \text { Lactobacillus plantarum. }{ }^{3} \text { Lactobacillus buchneri. } \\
\text { Fonte: Adaptado de Siqueira et al. (2007a). }\end{array}$} \\
\hline
\end{tabular}

Archivos de zootecnia vol. 59 (R), p. 36. 


\section{VALORNUTRITIVO DE SILAGENS DE FORRAGEIRAS TROPICAIS}

fermentação durante a ensilagem. Entretanto, alguns aditivos têm sofrido restrições pela possibilidade de contaminação do ambiente. Úreia como aditivo químico em proporções adequadas pode promover menores perdas fermentativas e promover efeito tóxico para fungos e leveduras. Nussio e Schmidt (2005) mencionaram que a recuperação do $\mathrm{N}$ nas silagens aditivadas com úreia é alta (superior a 70\%), o que deve ser considerado como benefício adicional na escolha dese aditivo.

Aditivos químicos como a uréia e o ácido benzóico podem melhorar a composição química de silagens de cana-de-açúcar, diminuindo a população de leveduras e mofos e reduzindo a produção de etanol e as perdas de MS e de carbohidratos. Segundo Santos et al. (2008), a utilização de óxido e carbonato de cálcio durante o período de conservação da silagem de cana-de-açúcar promoveu redução das perdas totais e gasosas, inibição da fermentação alcoólica e maior recuperação de carboidratos, resultando em silagem com valor nutritivo semelhante a da forragem in natura.

Oliveira et al. (2009), trabalhando com silagem de capim-tanzânia amonizada com quatro doses de uréia $(0 ; 0,25 ; 0,5$ e $0,75 \%$ base na matéria seca), observaram que a amonização nas doses utilizadas não alterou os teores de matéria seca, fibra em detergente neutro, fibra em detergente ácido, nitrogênio insolúvel em detergente neutro, nitrogênio insolúvel em detergente ácido, celulose, hemicelulose e lignina.

A associação de microrganismos a aditivos químicos, visando melhorar a eficiência no controle das fases de fermentação e estabilidade aeróbia, tem sido estudada por diferentes autores. Souza et al. (2008) avaliaram a eficácia de aditivo químico (uréia) e inoculantes microbianos (Lactobacillus buchneri e combinação de bactérias homo e heteroláticas Pedioccocus pentosassus) em silagens de cana-de-açúcar. A utilização de uréia e principalmente do aditivo Lactobacillus buchneri + Pedio- coccus foi eficaz em diminuir a pro-dução de etanol ( 1,30 e $2,75 \%$ vs $8,27 \%$ na silagem controle), as perdas de matéria seca (47 e $60 \%$ ) e o consumo de carboidratos solúveis (22 e 56\%) e em aumentar a digestibilidade in vitro da matéria seca (14,7 e 12,4\%), quando comparados à silagem controle, respectivamente. Apesar dos altos teores de ácido acético em todas as silagens, não foram verificados efeitos dos inoculantes sobre a população de leveduras. Os valores de $\mathrm{pH}$ e ácido lático da silagem com uréia foram maiores que os obtidos na silagem controle. As silagens com L. buchneri apresentaram maior produção de etanol (11,53\% vs 8,27\%, silagem controle), o que refletiu em perdas significativas e baixa recuperação de matéria seca, além de baixa digestibilidade pela perda de carboidratos solúveis e pelo acúmulo de FDN, que foram similares aos das silagens sem aditivo.

A associação de aditivos químicos com microbianos em silagens de cana-de-açúcar também foi avaliada por Siqueira et al. (2007a), cujos resultados estão apontados na tabela VI. Os autores empregaram uréia a $1,5 \%$; benzoatode sódio $0,1 \%$; ou hidróxido de sódio $(\mathrm{NaOH}) 1 \%$ na matéria natural como aditivos químicos combinados ou não com inoculantes microbianos (Propionibacterium acidipropionici + Lactobacillus plantarum ou Lactobacillus buchneri). A associação de L. buchneri e $\mathrm{N}_{\mathrm{a}} \mathrm{OH}$ reduziu as perdas por gases e efluentes e elevou a recuperação da MS. Após a abertura dos silos, destacou-se a atuação do benzoato de sódio em manter o $\mathrm{pH}$ com variação de apenas 0,1 unidade em cinco dias de exposição aeróbia e dos inoculantes L. buchneri e P. acidipropionici + L. plantarum em prolongar o tempo para elevação da temperatura de 34 horas nas silagens controle para 54 e 50 horas, respectivamente. Os autores concluiram que a ensilagem de cana-de-açúcar requer a inclusão de algum aditivo eficiente no controle das perdas quantitativas durante a fermentação e a exposição aeróbia. 


\section{SANTOS, GÓMEZ CASTRO, PEREA, GARCÍA, GUIM E PÉREZ HERNÁNDEZ}

Santos et al. (2008), avaliando o efeito do uso de aditivos químicos nas perdas de matéria seca, no perfil fermentativo e no valor nutritivo de silagens de cana-deaçúcar, observaram que as menores perdas fermentativas e gasosas foram observadas nas silagens com óxido ou carbonato de cálcio, que resultaram em maior taxa de recuperação de matéria seca. Da mesma forma, as silagens tratadas com estes aditivos apresentaram maior teor de carboidratos solúveis residuais e de ácido lático e reduzida fermentação alcoólica. As silagens tratadas com óxido e carbonato apresen- taram, no momento da abertura, maior teor de cinzas, menor concentração de componentes fibrosos e maiores coeficientes digestibilidade da matéria seca e da matéria orgânica. O teor de proteína encontrado nessas silagens foi semelhante ao observado na forragem fresca.

Siqueira et al. (2007b) avaliaram a ensilagem de cana-de-açúcar tratada com três aditivos químicos (uréia $1,5 \%$, benzoato de sódio $0,1 \%$ e hidróxido de sódio $1 \%$ ) mais o grupo controle e duas inoculações (Propionibacterium acidipropionici + Lactobacillus plantarum e Lactobacillus

Tabela VII. Teores de FDN, FDA e lignina (\%), antes da ensilagem e após a abertura dos silos, da cana-de-açúcar tratada ou não com aditivos químicos e bacterianos. (Contents of NDF, ADF and lignin before ensiling and after opening the silos, of sugar cane silage treated with chemical additives and bacterial).

\begin{tabular}{|c|c|c|c|c|c|c|c|c|}
\hline \multirow[b]{2}{*}{ Tratamento $^{1}$} & \multirow[b]{2}{*}{ Controle } & \multicolumn{2}{|c|}{ Ensilagem } & \multirow[b]{2}{*}{ Média } & \multirow[b]{2}{*}{ Controle } & \multirow[b]{2}{*}{ PROP2 } & \multicolumn{2}{|c|}{ Aberturta } \\
\hline & & PROP2 & $\mathrm{BUCH} 3$ & & & & $\mathrm{BUCH} 3$ & Média \\
\hline \multicolumn{9}{|l|}{ FDN } \\
\hline Controle & $52,1^{\mathrm{Ba}}$ & $52,3^{\mathrm{Bb}}$ & $55,1^{\mathrm{Aa}}$ & $53,1^{a}$ & $75,3^{\text {Aa }}$ & $74,3^{\mathrm{Aa}}$ & $66,9^{\mathrm{Ba}}$ & $72,2^{a}$ \\
\hline Uréia & $51,9^{\mathrm{Ba}}$ & $55,2^{\mathrm{Aa}}$ & $53,1^{\mathrm{Ba}}$ & $53,4^{a}$ & $72,2^{\mathrm{Ab}}$ & $70,5^{\mathrm{Ab}}$ & $67,5^{\mathrm{Ba}}$ & $70,1^{b}$ \\
\hline Benzoato & $51,7^{\mathrm{Ab}}$ & $50,4^{\mathrm{Ba}}$ & $53,0^{\mathrm{Aa}}$ & $51,7^{\mathrm{b}}$ & $70,4^{\mathrm{Ab}}$ & $69,2^{\mathrm{Ab}}$ & $61,7^{\mathrm{Bb}}$ & $67,1^{c}$ \\
\hline $\mathrm{NaOH}$ & $47,6^{\mathrm{Ab}}$ & $46,8^{A c}$ & $46,0^{A b}$ & $46,8^{c}$ & $59,2^{\mathrm{AC}}$ & $53,4^{\mathrm{Bc}}$ & $55,7^{\mathrm{BC}}$ & $56,1^{d}$ \\
\hline Média & $50,8^{A}$ & $51,2^{\mathrm{A}}$ & $51,1^{\mathrm{A}}$ & 51,3 & $69,3^{A}$ & $66,8^{B}$ & $63,0^{C}$ & 66,4 \\
\hline CV\% & & & & 1,82 & & & & 1,89 \\
\hline \multicolumn{9}{|l|}{ FDA } \\
\hline Controle & $34,8^{\mathrm{Aa}}$ & $35,6^{\mathrm{Aab}}$ & $35,0^{\mathrm{Aa}}$ & $35,1^{\mathrm{a}}$ & $48,7^{\text {Aa }}$ & $48,2^{\mathrm{ABa}}$ & $45,6^{\mathrm{Bb}}$ & $47,5^{a}$ \\
\hline Uréia & $35,2^{\text {Aba }}$ & $36,1^{\mathrm{Aa}}$ & $33,2^{\mathrm{Bab}}$ & $34,8^{\mathrm{ab}}$ & $45,8^{\mathrm{ABb}}$ & $43,7^{\mathrm{Bb}}$ & $46,6^{\mathrm{Ab}}$ & $45,3^{b}$ \\
\hline Benzoato & $35,0^{\mathrm{Aa}}$ & $34,4^{\mathrm{Aab}}$ & $31,2^{\mathrm{Bbc}}$ & $33,5^{\mathrm{bc}}$ & $44,7^{\mathrm{Bb}}$ & $47,4^{\mathrm{Aa}}$ & $49,7^{\mathrm{Aa}}$ & $47,3^{\mathrm{a}}$ \\
\hline $\mathrm{NaOH}$ & $35,9^{\mathrm{Aa}}$ & $33,4^{\mathrm{Bb}}$ & $30,0^{\mathrm{Cc}}$ & $33,1^{c}$ & $41,1^{\mathrm{BC}}$ & $39,5^{\mathrm{Bc}}$ & $44,3^{\mathrm{Ab}}$ & $41,6^{c}$ \\
\hline Média & $35,2^{A}$ & $34,9^{A}$ & $32,3^{\mathrm{B}}$ & 34,1 & $45,1^{\mathrm{B}}$ & $44,7^{\mathrm{B}}$ & $46,5^{\mathrm{A}}$ & 45,4 \\
\hline CV\% & & & & 3,25 & & & & 2,85 \\
\hline \multicolumn{9}{|l|}{ Lignina } \\
\hline Controle & $6,9^{\mathrm{Bb}}$ & $8,7^{\text {Aab }}$ & $7,7 A^{\mathrm{Bb}}$ & $7,8^{\mathrm{ab}}$ & $8,1^{\mathrm{Ba}}$ & $9,8^{\mathrm{Aa}}$ & $8,2^{\mathrm{Ba}}$ & $8,7^{\mathrm{b}}$ \\
\hline Uréia & $6,6^{\mathrm{Bb}}$ & $9,4^{\mathrm{Aa}}$ & $10,2^{\mathrm{Aa}}$ & $8,7^{a}$ & $7,3^{\mathrm{Aa}}$ & $7,3^{\mathrm{Ab}}$ & $8,1^{\mathrm{Aa}}$ & $7,6^{\mathrm{bc}}$ \\
\hline Benzoato & $9,6^{\mathrm{Aa}}$ & $7,2^{\mathrm{Bb}}$ & $7,1^{\mathrm{Bb}}$ & $8,0^{\mathrm{ab}}$ & $7,8^{\mathrm{Aa}}$ & $7,9^{\mathrm{Ab}}$ & $8,1^{\mathrm{Aa}}$ & $7,9^{\mathrm{ab}}$ \\
\hline $\mathrm{NaOH}$ & $8,0^{\text {Aab }}$ & $7,6^{\mathrm{Aab}}$ & $6,9^{A b}$ & $7,5^{\mathrm{b}}$ & $7,1^{\mathrm{Aa}}$ & $6,6^{\mathrm{Ab}}$ & $7,1^{\mathrm{Aa}}$ & $6,9^{c}$ \\
\hline Média & $7,8^{\mathrm{A}}$ & $8,2^{A}$ & $8,0^{A}$ & 8,0 & $7,6^{A}$ & $7,9^{\mathrm{A}}$ & $7,8^{A}$ & 7,8 \\
\hline CV\% & & & & 11,11 & & & & 7,90 \\
\hline
\end{tabular}

Médias seguidas de mesma letra, maiúscula na linha e minúscula na coluna, não diferem $(p<0,05)$ pelo teste de Tukey. ${ }^{11,5 \%}$ de uréia; $0,1 \%$ de benzoato de sódio e $1 \%$ de hidróxido de sódio. ${ }^{2}$ Propionibacterium acidipropionici + Lactobacillus plantarum. ${ }^{3}$ Lactobacillus buchneri.

Fonte: Adaptado de Siqueira et al. (2007b). 
buchneri) (tabela VII). As associações de $P$. acidipropionici ou $L$. buchneri com $\mathrm{NaOH}$, em comparação ao grupo controle, possibilitaram melhor preservação dos teores de MS (32,2 e 33,5 vs 27,4\%, respectivamente), FDN $(53,4 ; 55,7$ vs $75,3 \%)$, FDA $(39,5 ; 44,3$ vs $48,7 \%)$, lignina $(6,6 ; 7,1$ vs $8,1 \%)$ e CNF $(33,8 ; 31,7$ vs $14,9 \%)$ e, consequentemente, propiciaram os maiores valores de DIVMS (60,3; 63,2 vs 35,1\%). Esses valores podem ser atribuídos ao controle das leveduras pelos efeitos da associação dos aditivos. A ensilagem de cana-de-açúcar requer de forma contundente a inclusão de aditivo.

Trabalhando com silagem de cana-deaçúcar, Schmidt et al. (2007) avaliaram cinco silagens (base úmida): controle - cana-deaçúcar sem aditivos; uréia - cana-de-açúcar $+0,5 \%$ uréia; benzoato - cana-de-açúcar + $0,1 \%$ de benzoato de sódio; LP - cana-deaçúcar inoculada com Lactobacillus plantarum $\left(1 \times 10^{6} \mathrm{ufc} / \mathrm{g} \mathrm{MV}\right)$; LB - cana-deaçúcar inoculada com L. buchneri $\left(3,6 \times 10^{5}\right.$ $\mathrm{ufc} / \mathrm{g}$ forragem). A forragem foi armazenada em silos do tipo poço por 90 dias antes do fornecimento aos animais. A composição químico-bromatológica foi alterada após a ensilagem, em relação à cana-de-açúcar original, com redução no teor de carboidratos solúveis e na digestibilidade in vitro e elevação relativa nos teores de FDN e FDA. Os teores de etanol $(0,30 \%$ da MS $)$ e ácidos orgânicos $(0,99 \%$ de ácido lático e $2,31 \%$ de acético) foram baixos e semelhantes entre as silagens. Os aditivos aplicados na ensilagem não promoveram alterações no consumo e na digestibilidade aparente da MS.

Balieiro Neto et al. (2007) avaliaram os níveis 0,$5 ; 1$ e $2 \%$ de óxido de cálcio na ensilagem de cana-de-açúcar. Antes da ensilagem, doses crescentes de óxido promoveram redução dos teores de FDN, FDA e lignina e aumento da hemicelulose e da digestibilidade in vitro da matéria seca (DIVMS). No momento da abertura dos silos, os teores de FDN e FDA foram superio- res aos observados antes da ensilagem e menores nas silagens com doses mais altas de aditivo. Do momento da abertura ao $3^{\circ}$ dia não foi verificada alteração significativa nos teores de PB, FDN, FDA, lignina e hemicelulose ou na DIVMS. $\mathrm{O}$ aditivo no nível de $1 \%$ foi capaz de aumentar a digestibilidade, reduzir os constituintes da parede celular, manter teores de FDN e hemicelulose após abertura do silo e promover maior estabilidade da composição química e melhor qualidade da silagem.

O uso da queima para facilitar o processo de colheita da cana-de-açúcar para produção de açúcar e alcool é bastante utilizado no Nordeste do Brasil, devendo ser diferenciado o manejo de colheita da cana-de-açúcar a ser ensilada. Neste sentido, Bernardes et al. (2007) observaram que a silagem produzida com cana-de-açúcar queimada apresentou teor mais elevado de etanol. As altas temperaturas durante a queima destroem a camada de cera que envolve a parede celular, o que provoca rachaduras no colmo e consequente exudação de conteúdo celular (açúcares), aumentando a contaminação microbiana e ocasionando maior fermentação alcoólica.

\section{CONCLUSÕES}

1. A redução no tamanho da partícula no momento da ensilagem promove redução na fermentação butírica, proporcionando maior compactação e queda mais rápida do $\mathrm{pH}$ do material ensilado, além de menores perdas físicas na desensilagem. Entretanto, em silagens sem emurchecimento, a redução do tamanho da partícula pode promover maiores perdas por efluentes.

2. Silagem de capim-tifton 85 confeccionada com emurchecimento a teores médios de MS de $450 \mathrm{~g} / \mathrm{kg}$ MS apresenta melhores parâmetros de fermentação quanto a pH, N$\mathrm{NH}_{3}$ e poder tampão.

3. O aditivo absorvente utilizado em quantidade adequada eleva o teor de MS do material ensilado e promove ambiente me- 


\section{SANTOS, GÓMEZ CASTRO, PEREA, GARCÍA, GUIM E PÉREZ HERNÁNDEZ}

nos favorável para o desenvolvimento das leveduras, contribuindo também para menores perdas de efluentes.

4. Silagem de cana-de-açúcar acrescida de uréia e aditivos absorventes (mandioca desidratada) apresenta melhor valor nutritivo e maior consumo e digestibilidade da PB.

5. O uso da L. buchneri promove diminuição de $\mathrm{pH}$, da concentração de ácido lático e do número de leveduras, bem como eleva a concentração de ácido acetico e promove maior estabilidade aeróbica das silagens inoculadas. Por outro lado, a inoculação aumenta a concentração de áci-

\section{BIBLIOGRAFIA}

Akintokun, A., Jolaosho, A.O. and Afolabi, R.O. 2007. Effect of L. plantarum and carbohydrase on microbes and composition of $T$. procumbens silage. Arch. Zootec., 56: 145-156.

Amaral, R.C., Bernardes, T.F., Siqueira, G.R. e Reis, R.A. 2007. Características fermentativas e químicas de silagens de capim-marandu produzidas com quatro pressões de compactação. Rev. Bras. Zootecn., 36: 532-539.

Balieiro Neto, G., Siqueira, G.R., Reis, R.A., Nogueira, J.R., Roth, M.T.P. e Roth, A.P.T.P. 2007. Óxido de cálcio como aditivo na ensilagem de cana-de-açúcar. Rev. Bras. Zootecn., 36: 1231-1239.

Bergamaschine, A.F., Passipiéri, M., Veriano Filho, W.V., Isepon, O.J. e Correa, L.A. 2006. Qualidade e valor nutritivo de silagens de capim-marandu (B. brizantha cv. Marandu) produzidas com aditivos ou forragem emurchecida. Rev. Bras. Zootecn., 35: 1454-1462.

Bernardino, F.S., Garcia, R., Rocha, F.C., Souza, A.L. e Pereira, O.G. 2005. Produção e características do efluente e composição broma-tológica da silagem de capim-elefante contendo diferentes níveis de casca de café. Rev. Bras. Zootecn., 34 (supl.): 2185-2191.

Bernardes, T.F., Reis, R.A. and Moreira, A.L. 2005. Fermentative and microbiological profile of Marandu-grass ensiled with citrus pulp pellets. Scientia Agricola, 62: 214-220

Bernardes, T.F., Reis, R.A., Siqueira, G.R., Berchielli, T.T. e Coan, R.M. 2007. Avaliação da queima e da adição de milho desintegrado com do propiônico e etanol e diminui a concentração de carbohidratos solúveis nas silagens de gramíneas e das com poucos grãos, porém não se observa em silagem de milho, o que sugere efeito específico microrganismo-cultura.

6. Benefícios sobre a aplicação de aditivos enzimáticos ou sua associação com inoculantes bacterianos são controversos na literatura disponível e dependentes das condições locais, concentração e tipo de inoculante, método de aplicação, qualidade da planta forrageira, microflora pré-existente, entre outros fatores.

palha e sabugo na ensilagem de cana-de-açúcar. Rev. Bras. Zootecn., 36: 269-275.

Cabral Jr., C.R., Miranda, E.C., Pinheiro, D.M., Guimarães, I.G., Andrade, M.V.M. e Pinto, M.S.C. 2007. Dinâmica fermentativa de silagens de Gliricidia sepium. Arch. Zootec., 56: 249-252. 2007.

Cândido, M.J.D., Neiva, J.N.M., Rodriguez, N.M. e Ferreira, A.C.H. 2007. Características fermentativas e composição química de silagens de capim-elefante contendo subproduto desidratado do maracujá. Rev. Bras. Zootecn., 36 (supl.): 1489-1494.

Castro, F.G.F., Nussio, L.G., Haddad, C.M., Campos, F.P., Coelho, R.M., Mari, L.J. e Toledo, P.A. 2006. Características de fermentação e composição químico-bromatológica de silagens de capim-tifton 85 confeccionadas com cinco teores de matéria seca. Rev. Bras. Zootecn., 35: 7-20.

Coan, R.M., Vieira, P.F., Silveira, R.N., Reis, R.A., Malheiros, E.B. e Pedreira, M.S. 2005. Inoculante enzimático-bacteriano, composição química e parâmetros fermentativos das silagens dos capins tanzânia e mombaça. Rev. Bras. Zootecn., 34: 416-424.

Cysneiros, C.S.S., Franco, G.L., Ulhoa, C.J., Diogo, J.M.S. e Ramos, A.K.B. 2006. Efeito de enzimas fibrolíticas sobre a composição química da silagem de milho. Ciên. Anim. Bras., 7: 339-348.

Ferrari Junior, E., Paulino, V.T., Possenti, R.A. e Lucenas, T.L. 2009. Aditivos em silagem de capim elefante paraíso (Pennisetum hybridum 


\section{VALORNUTRITIVO DE SILAGENS DE FORRAGEIRAS TROPICAIS}

cv. Paraíso). Arch. Zootec., 58: 185-194.

Freitas, A.W. P., Pereira, J.C., Rocha, F.C., Detmann, E., Ribeiro, M.D., Costa, M.G. e Leonel, F.P. 2006a. Características da silagem de cana-deaçúcar tratada com inoculante bacteriano e hidróxido de sódio e acrescida de resíduo da colheita de soja. Rev. Bras. Zootecn., 35: 48-59.

Freitas, A.W.P., Pereira, J.C., Rocha, F.C., Costa, M.G., Leonel, F.P. e Ribeiro, M.D. 2006b. Avaliação da qualidade nutricional da silagem de cana-de-açúcar com aditivos microbianos e enriquecida com resíduo da colheita de soja. Rev. Bras. Zootecn., 35: 38-47.

Grise, M.M., Martins, R.L., Fernandes, A.C., Rossi Junior, P. e Piazzetta, R.G. 2006. Efeito do uso de inoculantes sobre $\mathrm{o} \mathrm{pH}$ e a composição bromatológica da silagem de sorgo (Sorghum bicolor L. Moench). Arch. Vet. Sci., 11: 13-16. Ítavo, C.C.B.F., Morais, M.G., Ítavo, L.C.V., Souza, A.R.D.L., Davy, F.C.A., Albertini, T.Z., Costa, C., Lempp, B. e Jobim, C.C. 2006. Padrão de fermentação e composição química de silagens de grãos úmidos de milho e sorgo submetidas ou não a inoculação microbiana. Rev. Bras. Zootecn., 35: 655-664.

Jalilvand, G., Naserian, A., Kebreab, E., Odongo, N.E, Valizadeh, R., Shahroodi, E.F., Lopez, S. and France, J. 2008. Rumen degradation kinetics of alfalfa hay, maize silage and wheat straw treated with fibrolytic enzymes. Arch. Zootec., 57: 155-164.

Jobim, C.C., Gonçalves, G.D. e dos Santos, G.T. 2001. Qualidade sanitária de grãos e de forragens conservadas versus desempenho animal e qualidade de seus produtos. In: Jobim, C.C, U. Cecato, J.C. Damasceno e G.T. dos Santos (Eds.). Simpósio Sobre Produção e Utilização de Forragens Conservadas. Anais... UEM/CCA/DZO. Maringá. pp. 242-261.

Jobim, C.C., Nussio, L.G., Reis, R. A. e Schmidt, P. 2007. Avanços metodológicos na avaliação da qualidade da forragem conservada. Rev. Bras. Zootecn., 36 (suppl): 101-119.

Kleinschmit, D.H. and Kung Jr., L. 2006. Metaanalysis of the effects of Lactobacillus buchneri on the fermentation and aerobic stability of corn and grass and small-grain silages. J. Dairy Sci., 89: 4005-4013

Kleinschmit, D.H., Schmidt, R.J. and Kung Jr., L. 2005. The effects of various antifungal additives on the fermentation and aerobic stability of corn silage. J. Dairy Sci., 88: 2130-2139

Krizsan, S.J. and Randby, Å.T. 2007. The effect of fermentation quality on the voluntary intake of grass silage by growing cattle fed silage as the sole feed. J. Anim. Sci., 85: 984-996.

Lopes, J., Evangelista, A.R. e Rocha, G.P. 2007. Valor nutricional da silagem de cana-de-açúcar acrescida de uréia e aditivos absorventes de umidade. Rev. Bras. Zootecn., 36 (supl.): 11551161.

Loures, D.R.S., Nussio, L.G., Paziani, S.F., Pedroso, A.F., Mari, L.J., Ribeiro, J.L., Zopollatto, M., Schimdt, P., Junqueira, M.C., Packer, I.U. e Campos, F.P. 2005. Composição bromatológica e produção de efluente de silagens de capimTanzânia sob efeitos do emurchecimento, do tamanho de partícula e do uso de aditivos biológicos. Rev. Bras. Zootecn., 34: 726-735.

Matos, D.S., Guim, A., Batista, Â.M.V., Pereira, O.G. e Silva, V.M. 2005. Composição química e valor nutritivo da silagem de maniçoba (Manihot epruinosa). Arch. Zootec., 54: 619-629.

McDonald, P.J., Henderson, A.R. and Heron, S.J.E. 1991. The biochemistry of silage. $2^{\mathrm{a}}$ Ed. Mallow Chalcombe Publications. $340 \mathrm{pp}$

Mittelmann, A., Sobrinho, F.S., Oliveira, J.S., Fernandes, S.B.V., Lajús, C.A., Miranda, M., Zanatta, J.C. e Moletta, J.L. 2005. Avaliação de híbridos comerciais de milho para utilização como silagem na Região Sul do Brasil. Ciência Rural, 35: 684-690.

Muck, R.E. and Kung Jr., L. 1997. Effects of silages additives on ensiling. In: The silage: field to feed bunk North American conference, 1997, Hershey. Proceedings... National Regional Agricultural Engineering Service. Hershey. pp. 187-199.

Neumann, M., Mühlbach, P.R.F., Nörnberg, J.L., Ost, P.R., Restle, J., Sandini, I.E. e Romano, M.A 2007a. Características da fermentação da silagem obtida em diferentes tipos de silos sob efeito do tamanho de partícula e da altura de colheita das plantas de milho. Ciência Rural, 37: 847-854

Neumann, M., Mühlbach, P.R.F., Nörnberg, J.L., Ost, P.R. e Lustosa, S.B.C. 2007b. Efeito do tamanho de partícula e da altura de corte de plantas de milho na dinâmica do processo fermentativo da silagem e no período de 


\section{SANTOS, GÓMEZ CASTRO, PEREA, GARCÍA, GUIM E PÉREZ HERNÁNDEZ}

desensilagem. Rev. Bras. Zootecn., 36 (supl.): 1603-1613.

Nussio, L. G. e Schmidt, P. 2005. Silagens de canade-açúcar para bovinos leiteiros: aspectos agronômicos e nutricionais. In: F.A.P. Santos, J.C. de Moura, V.P. de Faria (Org.). Anais... Simpósio sobre Bovinocultura Leiteira: Visão Técnica e Econômica da Produção Leiteira. 5. 1 ed. FEALQ. Piracicaba. 1: 193-218.

Oliveira, H.C., Pires, A.J.V., Oliveira, A.C., Rocha Neto, A.L., Matos Neto, U., Carvalho, G.G.P., Veloso, C.M. e Oliveira, U.L.C. 2009. Perdas e valor nutritivo da silagem de capim-tanzânia amonizado com uréia. Arch. Zootec., 58: 195202.

Pedroso, A.F., Nussio, L.G., Paziani, S.F., Loures, D.R.S., Igarasi, M.S., Coelho, R.M., Packer, I.H., Horii, J. e Gomes, L.H. 2005. Fermentation and epiphytic microflora dynamics in sugar cane silage. Sci. Agric. 62: 427-432.

Peláez Acero, A., Meneses Mayo, M., Miranda Romero, L.A., Megías Rivas, M.D., Barcena Gama, R. y Loera, O. 2008. Ventajas de la fermentación sólida con Pleurotus sapidus en ensilajes de caña de azúcar. Arch. Zootec., 57: 25-33.

Penteado, D.C.S., Santos, E.M., Carvalho, G.G.P., Oliveira, J.S., Zanine, A.M., Pereira, O.G. e Ferreira, C.L.L.F. 2007. Inoculação com Lactobacillus plantarum da microbiota em silagem de capim-mombaça. Arch. Zootec., 56: 191-202.

Pereira, O.G., Rocha, K.D. e Ferreira, C.L.L.F. 2007. Composição química, caracterização e quantificação da população de microrganismos em capim-elefante cv. Cameroon (Pennisetum purpureum, Schum.) e suas silagens. Rev. Bras. Zootecn., 36:1742-1750.

Pereira, J.R. e Reis, R.A. 2001. Produção de silagem pré-secada com forrageiras temperadas e tropicais In: Jobim, C.C, Cecato, U., Damasceno, J.C., Santos, G.T. (eds.). Simpósio Sobre Produção e Utilização de Forragens Conservadas. Anais... UEM/CCA/DZO. Maringá. pp. 64-86.

Queiroz, O.C.M. 2006. Associação de aditivos microbianos na ensilagem e o desempenho de vacas em lactação recebendo silagem de canade-açúcar comparada a volumosos tradicionais. Dissertação (Mestrado). Escola Superior de
Agricultura Luiz de Queiroz. Piracicaba. 99 pp. Rocha, K.D., Pereira, O.G., Valadares Filho, S.C., Oliveira, A.P., Pacheco, L.B.B. e Chizzotti, F.H.M. 2006. Valor nutritivo de silagens de milho (Zea mays L.) produzidas com inoculantes enzimobacterianos. Rev. Bras. Zootecn., 35: 389-395.

Rodrigues, P.H.M., Borgatti, L.M.O., Gomes, R.W., Passini, R. e Meyer, P.M. 2005a. Efeito da adição de níveis crescentes de polpa cítrica sobre a qualidade fermentativa e o valor nutritivo da silagem de capim-elefante. Rev. Bras. Zootecn., 34: 1138-1145.

Rodrigues, P.H.M., Almeida, T.F., Meyer, P.M. e Borgatti, L.M.O. 2005b. Valor nutritivo da silagem de girassol inoculada com bactérias ácidoláticas. Rev. Bras. Zootecn., 34 :340-344.

Ruiz, B.O., Castillo, Y., Anchondo, A., Rodríguez, C., Beltrán, R., La O, O. y Payán, J. 2009. Efectos de enzimas e inoculantes sobre la composición del ensilaje de maíz. Arch. Zootec., 58: 163-172.

Santos, E.M., Zanine, A.M., Ferreira, D.J., Oliveira, J.S., Penteado, C.S. e Pereira, O.G. 2008. Inoculante ativado melhora a silagem de capimtanzânia (Panicum maximum). Arch. Zootec., 57: 35-42.

Santos, M.C., Nussio, L.G., Mourão, G.B., Schmidt, P., Mari, L.J. e Ribeiro, J.L. 2008. Influência da utilização de aditivos químicos no perfil da fermentação, no valor nutritivo e nas perdas de silagens de cana-de-açúcar. Rev. Bras. Zootecn., 37: 1555-1563.

Schmidt, P., Mari, L.J., Nussio, L.G., Pedroso, A. F., Paziani, S.F. e Wechsler, F.S. 2007. Aditivos químicos e biológicos na ensilagem de cana-deaçúcar. 1. Composição química das silagens, ingestão, digestibilidade e comportamento ingestivo. Rev. Bras. Zootecn., 36 (supl.): 16661675.

Schocken-Iturrino, R.P., Reis, R.A., Coan, R.M., Bernardes, T.F., Panizzi, R.C., Poiatti, M.L. e Pedreira, M.S. 2005. Alterações químicas e microbiológicas nas silagens de capim-tifton 85 após a abertura dos silos. Rev. Bras. Zootecn., 34: 464-471.

Siqueira, G.R., Reis, R.A., Schocken-Iturrino, R.P., Pires, A.J.V., Bernardes, T.F. e Amaral, R.C. 2007a. Perdas de silagens de cana-de-açúcar tratadas com aditivos químicos e bacterianos. Rev. Bras. Zootecn., 36 (supl.): 2000-2009. Siqueira, G.R., Reis, R.A., Schocken-Iturrino, R.P., 


\section{VALORNUTRITIVO DE SILAGENS DE FORRAGEIRAS TROPICAIS}

Bernardes, T.F., Pires, A.J.V., Roth, M.T.P. e Roth, A.P.T.P. 2007b. Associação entre aditivos químicos e bacterianos na ensilagem de cana-de-açúcar. Rev. Bras. Zootecn., 36: 789798.

Sousa, D.P., Mattos, W.R.S., Nussio, L.G., Mari, L.J., Ribeiro, J.L. e Santos, M.C. 2008. Efeito de aditivo químico e inoculantes microbianos na fermentação e no controle da produção de álcool em silagens de cana-de-açúcar. Rev. Bras. Zootecn., 37: 1564-1572.

Velho, J.P., Mühlbach, P.R.F., Genro, T.C.M., Sanchez, L.M.B., Nörnberg, J.L., Orqis, M.C. e Falkenberg, J.R. 2006a. Alterações bromatológicas nas silagens de milho submetidas a crescentes tempos de exposição ao ar após "desensilagem". Ciência Rural, 36: 916-923.

Velho, J.P., Mühlbach, P.R.F., Genro, T.C.M., Velho, I.M.P.H., Nörnberg, J.L., Orqis, M.G. e Kessler, J.D. 2006b. Alterações bromatológicas nas frações dos carboidratos de silagens de milho "safrinha" sob diferentes tempos de exposição ao ar antes da ensilagem. Rev. Bras. Zootecn.,
35 (supl.): 1621-1628.

Velho, J.P., Mühlbach, P.R.F., Nörnberg, J.L., Velho, I.M.P.H., Genro, T. C. M. e Kessler, J.D. 2007. Composição bromatológica de silagens de milho produzidas com diferentes densidades de compactação. Rev. Bras. Zootecn., 36 (supl.): 1532-1538.

Vilela, H.H., Rezende, A.V., Vieira, P.F., Andrade, G.A., Evangelista, A.R. e Almeida, G.B.S. 2008. Valor nutritivo de silagens de milho colhido em diversos estádios de maturação. Rev. Bras. Zootecn., 37: 1192-1199.

Vieira, M.M.M., Cavalcante, M.A.B., Neiva, J.N.M. e Cândido, M.J.D. 2007. Valor nutritivo de silagens de capim elefante contendo níveis de farelo de babaçu. Arch. Zootec., 56: 257-260.

Yan, T. and Agnew, R.E. 2004. Concentrations using nutrient compositions and fermentation characteristics Prediction of nutritive values in grass silages: I. Nutrient digestibility and energy. J. Anim. Sci., 82: 1367-1379.

Woolford, M.K. 1984. The silage fermentation. Marcel Dekker. New York. 322 pp. 